\title{
The First Amendment Right of Access to Civil Trials After Globe Newspaper Co. $v$. Superior Court
}

In Richmond Newspapers, Inc. v. Virginia ${ }^{1}$ and Globe Newspaper Co. v. Superior Court, ${ }^{2}$ the United States Supreme Court established that the press and public have a right of access to criminal trials guaranteed by the first amendment. ${ }^{3}$ Although the Constitution nowhere explicitly guarantees the right to attend criminal trials, ${ }^{4}$ the Court reasoned that such a right is historically rooted in our system of justice and implicit in the first amendment's "core purpose" of assuring free public discussion. ${ }^{8}$ In Globe, the Court held that any denial of this right must be "necessitated by a compelling governmental interest" and "narrowly tailored to serve that interest." 6

This comment argues that the constitutional right of access 7 announced in Richmond and Globe extends to civil trials. ${ }^{8}$ Civil

1448 U.S. 555 (1980).

2457 U.S. 596 (1982).

s "Congress shall make no law . . . abridging the freedom of speech, or of the press; or of the right of the people peaceably to assemble, and to petition the Government for a redress of grievances." U.S. CoNST. amend. I.

See Globe, 457 U.S. at 604; Richmond, 448 U.S. at 579.

- Richmond, 448 U.S. at 575. The Court has recently extended the right of access to pretrial voir dire for the same reasons. See Press-Enterprise Co. v. Superior Court, 104 S. Ct. 819, 821-24 (1984).

- 457 U.S. at 606-07.

7 Whether the right of access recognized in Richmond and Globe should include the right to inspect and copy evidence, though related to the subject of the present comment, is beyond its scope. Nonetheless, it is worthwhile to note in passing that many courts have held that the principles mandating access to judicial proceedings also guarantee the right to inspect and copy court documents. See, e.g., Brown \& Williamson Tobacco Corp. v. F.T.C., 710 F.2d 1165, 1177 (6th Cir. 1983); United States v. Carpentier, 526 F. Supp. 292, 294-95 (E.D.N.Y. 1981), aff'd on other grounds, 689 F.2d 21 (2d Cir. 1982), cert. denied, 103 S. Ct. 735 (1983). But see Belo Broadcasting Corp. v. Clark, 654 F.2d 423, 426-28 (5th Cir. 1981) (disallowing access to audiotapes played at criminal trial); United States v. Hubbard, 650 F.2d 293, 316-17 (D.C. Cir. 1980) (Richmond does not undercut earlier conclusion of the Court that right to inspect evidence is best left to trial court's discretion).

- The term civil suit, as used throughout this comment, refers to any trial instituted by complaint and not by prosecution through indictment or information. In Cox Enterprises v. Vaccocu, 455 U.S. 994 (1982), the Supreme Court denied certiorari on a case raising the question of whether pretrial hearings in a shareholders' derivative suit could constitutionally be closed to the public. See Note, After Richmond Newspapers: A Public Right to Attend 
trials, like criminal trials, have historically been open and concern matters vital to the "free discussion of governmental affairs." Moreover, a right of access to civil, like criminal, trials plays a "significant role in the functioning of the judicial process and the government as a whole."10

Like the right to attend criminal trials, the right to attend civil trials is not absolute, and may be restricted where necessary to protect "compelling" governmental interests." The comment will explore four such interests: safeguarding national security, protecting trade secrets, ensuring the anonymity of juvenile offenders and witnesses, and safeguarding the rights of privacy. It will argue that these interests are sufficiently "compelling" to overcome the press's right of access only where an open trial would destroy the right sought to be vindicated at trial or jeopardize the physical safety of witnesses or parties. As in criminal cases, the need for closure must be determined on a case-by-case basis, and any orders mandating closure must be narrowly drawn. ${ }^{12}$

\section{The Right of Access to Criminal Trials: Richmond and Globe.}

\section{A. Richmond: Conflicting Analyses}

In Richmond Newspapers, Inc. $v$. Virginia, ${ }^{13}$ a defendant facing his fourth trial on murder charges successfully moved to close the entire proceedings to the press and public. ${ }^{14}$ Richmond Newspapers, whose reporter had been covering the trial, sought an immediate hearing to vacate the closure order. ${ }^{15}$ The trial court denied Richmond Newspapers's motion on the ground that closure was necessary to guarantee a fair trial. ${ }^{16}$ The Virginia Supreme Court, finding no reversible error, dismissed the newspaper's mandamus petition and denied the newspaper's petition for appeal. ${ }^{17}$

Civil Trials, 4 CoMm/ENT L.J. 291, 292 n.9 (1982).

- Globe, 457 U.S. at 604 (quoting Mills v. Alabama, 384 U.S. 214, 218 (1966)).

10 Id. at 606 .

11 Id. at 606-07.

12 Cf. id. (articulating a similar test for closing a criminal trial); Richmond, 448 U.S. at 581 ("Absent an overriding interest articulated in findings, the trial of a criminal case must be open to the public.").

13448 U.S. 555 (1980).

14 Id. at 559-60.

18 Id. at 560 .

16 Id. at 560-61.

17 Id. at 562 . 
By a vote of seven to one, ${ }^{18}$ the United States Supreme Court reversed, holding that the order violated the public and press's first amendment right of access to criminal trials. No majority coalesced to support a single rationale for this holding. ${ }^{19}$

Chief Justice Burger, the author of the plurality opinion, relied primarily on historical evidence to support his finding of a right to attend criminal trials, ${ }^{20}$ and analogized the right of access to the courtroom to the right of assembly in places, such as streets and parks, that have been "traditionally open" to the public. ${ }^{21}$ The Chief Justice also emphasized that a guarantee of access would benefit society by increasing trust in the judical system. ${ }^{22}$

In his concurrence, Justice Brennan emphasized the "structural role" played by the first amendment in "securing and fostering our republican system of self-government."23 Implicit in this structural role is the principle that public debate should be not only uninhibited, but also informed. ${ }^{24}$ The right of access is properly a matter of first amendment concern because it advances the "broadly political interests" of a nation committed to self-government and to "maintaining public confidence in the administration of justice."25 Finally, Justice Brennan noted that openness im-

18 Justice Powell did not participate, id. at 581, and Justice Rehnquist dissented on the ground that nothing in the first, sixth, ninth, or fourteenth amendments authorized the Supreme Court to review state court decisions regarding trial closure, id. at 604.

18 Justices White and Stevens joined Chief Justice Burger's plurality opinion, id. at 558, but each also wrote a separate concurring opinion, $i d$. at 582 . Justice Brennan, joined by Justice Marshall, concurred in the judgment and wrote a separate concurrence. Id. at 584. Justices Stewart and Blackmun wrote separate concurrences. Id. at 598,601. Numerous commentators have discussed the various positions of the Justices. See BeVier, Like Mackerel in the Moonlight: Some Reflections on Richmond Newspapers, 10 HorsTrA L. REv. 311 (1982); Fenner \& Koley, Access to Judicial Proceedings: To Richmond Newspapers, and Beyond, 16 Harv. C.R.-C.L. L. REv. 415 (1981); Note, Public Trials and a First Amendment Right of Access: A Presumption of Openness, 60 NEB. L. REv. 169 (1981); Comment, Is the Right of Access to Trials an Instance of a First Amendment Right to Know?, 42 OHIo ST. L.J. 831 (1981). Of particular interest is Note, supra note 8, which analyzes the right of access to civil trials before Globe.

${ }^{20} 448$ U.S. at 569-571 (plurality opinion of Burger, C.J.).

${ }^{21} I d$. at 577-78. This rationale was also adopted by Justice Stewart. Id. at 599-600 (Stewart, J., concurring in the judgment). For criticism of this position, see BeVier, supra note 19, at 328-31.

${ }_{22}^{22} 448$ U.S. at 572 (plurality opinion of Burger, C.J.).

${ }^{23} \mathrm{Id}$. at 587 (Brennan, J., concurring in the judgment) (emphasis in original).

24 Id. Justice Brennan's theory appears to draw heavily on A. MeikLejohn, Free Speech and Its Relation to Self-Government (1948). See Brennan, Address, 32 Rutgers L. Rev. 173, 176-77 (1979) (discussing "structural" model of first amendment); Brennan, The Supreme Court and the Meiklejohn Interpretation of the First Amendment, 79 Harv. L. REv. 1 (1965) (comparing Meiklejohn's views on the first amendment to those found in Supreme Court opinions).

${ }^{25} 448$ U.S. at 594-95 (Brennan, J., concurring in the judgment). 
proves the judicial process by serving to check abuse and promote "accurate factfinding."26

Justices White and Blackmun each wrote separately to note that the Court's holding would have been unnecessary had the Court not earlier denied a public right of access under the sixth amendment guarantee of a public trial. ${ }^{27}$ Justice Stevens read the plurality opinion broadly to suggest that any "arbitrary interference with access to important [governmental] information" may violate the first amendment. ${ }^{28}$ Justice Stewart, concurring in the judgment, emphasized that the right of access to trial proceedings is "not absolute"29 and may be restricted to preserve courtroom decorum ${ }^{30}$ or to protect asserted reputational and proprietary interests. ${ }^{31}$ Such interests, Justice Stewart noted, need not be constitutional to justify denial of access. ${ }^{32}$

The multiplicity of views represented in the seven separate opinions in Richmond left the newly established right of access largely undefined. That definition was supplied the following year in Globe Newspaper Co. v. Superior Court.

\section{B. Globe: The Importance of Function Confirmed}

In Globe Newspaper Co. v. Superior Court, ${ }^{\text {ss }}$ the Supreme Court clarified and strengthened the right of access announced in Richmond. Faced with a state statute barring press and public access to criminal trials of alleged sex offenders during the testimony of minor victims, the Court held the statute an invalid infringement of the first amendment right of access. ${ }^{34}$ Justice Brennan, writing for the majority, ${ }^{3 \mathrm{~B}}$ reasoned that the first amendment pro-

26 Id. at 596.

27 Id. at 581-82 (White, J., concurring) (discussing Gannett Co. v. DePasquale, 443 U.S. 368 (1979)), id. at 603-04 (Blackmun, J., concurring in the judgment) (same).

2s Id. at 583 (Stevens, J., concurring).

20 Id. at 600 (Stewart, J., concurring in the judgment).

${ }^{30}$ Id.

sI Id. at 600 n.5.

32 Id.

ss 457 U.S. 596 (1982).

st Id. at 610-11. The case arose when Globe Newspaper Co. unsuccessfully attempted to gain access to a rape trial conducted in Massachusetts Superior Court. Pursuant to Mass. Ann. Laws. ch. 278, $\S 16$ A (Michie/Law. Co-op. 1980), the judge ordered the trial closed in the expectation that two minor rape victims would testify. Globe's petition for extraordinary relief to a Justice of the Supreme Judicial Court of Massachusetts was denied. On appeal, the full court dismissed Globe's appeal, concluding that the mandatory closure rule of $\S 16 \mathrm{~A}$ met the standards of Richmond. See Globe, 457 U.S. at 600 .

ss Justices White, Marshall, Blackmun, and Powell joined Justice Brennan's majority opinion. Globe, 457 U.S. at 598. Justice O'Connor wrote a separate concurrence. Id. at 611. 
tection of speech serves to ensure effective individual participation in "our republican system of self-government." The first amendment therefore "embraces" a right of access to criminal trials in order "to ensure that this constitutionally protected 'discussion of governmental affairs is an informed one." "37

\section{The Reasoning of Globe and Richmond}

While in neither Globe nor Richmond did the Court purport to establish a test for determining a right of access to all governmental proceedings, its analysis in Globe can be taken as a model for determining whether a particular governmental proceeding must be open to the public. The Court held that two features of the criminal justice system explain why "a right of access to criminal trials in particular is properly afforded protection by the First Amendment." Fis First, "the criminal trial historically has been open." ${ }^{39}$ Second, the right of access "plays a particularly significant role in the functioning of the judicial process and the government as a whole." ${ }^{40}$ Once the right of access to trials is established by reference to history and function, only a "compelling governmental interest" can justify a denial of access. ${ }^{41}$ The Court's treatment of these steps-history, function, and compelling interest-will be examined in some detail.

1. The Historical Analysis. Both Chief Justice Burger's plurality opinion in Richmond and Justice Brennan's majority opinion in Globe rely on the observation that the Anglo-American criminal trial "has long been presumptively open." openness"43 is important for two reasons. First, such a tradition commands respect because "the Constitution carries the gloss of history." 4 A right known to the framers of the Constitution might have been thought by them to be among those rights not specifi-

Chief Justice Burger, with whom Justice Rehnquist joined, wrote a dissenting opinion. Id. at 612. Justice Stevens wrote a separate dissent. Id. at 620.

s6 Id. at 604; see supra note 24.

${ }^{37}$ Id. at 605 (quoting Mills v. Alabama, 384 U.S. 214, 218 (1966)).

ss Id. at 605 (emphasis in original).

39 Id.

${ }^{40} I d$. at 606 .

41 Id. at 606-07.

12 Id. at 605 (quoting Richmond, 448 U.S. at 569). The Court also relied primarily on the historical openness of jury selection proceedings in Press-Enterprises Co. v. Superior Court, $104 \mathrm{~S}$. Ct. 819, 822-23 (1984), to establish a first amendment right of access to voir dire.

43 Globe, 457 U.S. at 605.

4 Id. (quoting Richmond, 448 U.S. at 589 (Brennan, J., concurring)). 
cally guaranteed but nonetheless protected by the Constitution. ${ }^{45}$ Second, the uniform history of open trials suggests " the favorable judgment of experience." "46 Open trials persist because experience has proven that they work. They have therefore evolved into an indispensable feature of the criminal justice system. ${ }^{47}$

Globe suggests that in looking to historical evidence to support a first amendment right of access, one must look to the history of the functions served by a particular proceeding, and not merely to the traditional openness of that proceeding itself. That pretrial hearings were not open at common law, for example, is, under Globe, irrelevant since the functions performed by such hearings were originally served by trials themselves. ${ }^{48}$ By emphasizing the functional nature of the proceeding, Globe suggests that history may not be used as an absolute limit in determining whether trialtype proceedings must be constitutionally open.

2. The Functional Analysis. The Court in Globe also recognized the "institutional value of the open criminal trial."49 Public scrutiny of the criminal trial "enhances the quality and safeguards the integrity of the factfinding process, with benefits to both the defendant and to society as a whole." ${ }^{50}$ The benefits to the defendant were catalogued by both Chief Justice Burger's plurality opinion in Richmond and Justice Brennan's concurrence. Public presence at the trial acts as a "check" on "possible abuse of judicial power," aids in "accurate factfinding," encourages witnesses to testify truthfully, ${ }^{63}$ makes possible the location of key witnesses whose whereabouts are unknown to the parties, ${ }^{54}$ and discourages

4s As Chief Justice Burger said in Richmond, "[t]he Bill of Rights was enacted against the backdrop of the long history of trials being presumptively open." 448 U.S. at 575.

467 U.S. at 605 (quoting Richmond, 448 U.S. at 589 (Brennan, J., concurring)).

47 See Richmond, 448 U.S. at 569 (Openness "has long been recognized as an indispensable attribute of an Anglo-American trial.").

48 See United States v. Chagra, 701 F.2d 354, 362-63 (5th Cir. 1983) (pretrial bail reduction hearing held presumptively open, despite lack of historical evidence of bail hearing openness, due to the growing significance of such hearings in the trial process); United States v. Criden, 675 F.2d 550, 555 (3d Cir. 1982) (historical analysis found irrelevant in determining right of access to pretrial suppression, due process, and entrapment hearings due to the growing "importance of pretrial procedure to that of trial"); cf. In re Westchester Rockland Newspapers, Inc. v. Leggett, 48 N.Y.2d 430, 440, 399 N.E.2d 518, 523, 423 N.Y.S.2d 630, 636 (1979) (noting that if access to pretrial proceedings is foreclosed, "most of the work of the criminal courts will be done behind closed doors").

10 Globe, 457 U.S. at 606.

so Id.

s1 Richmond, 448 U.S. at 596 (Brennan, J., concurring).

1 Id.

ss Id. at 569 (plurality opinion of Burger, C.J.), 597 (Brennan, J., concurring).

st Id. at 596-97 (Brennan, J., concurring). 
biased decision making. ${ }^{55}$ The benefits to society are equally great: open trials deepen public understanding of the judge's decisions, ${ }^{50}$ heighten respect for the judicial process, ${ }^{57}$ and provide "significant community therapeutic value"s8 by allowing the public, in watching "the accusation and conviction" of criminals who have committed a wrong against society, to "satisfy [its] latent "urge to punish." "s9

The Court's opinion in Globe suggests that access to any particular governmental institution, to be constitutionally protected, must be more than merely consistent with the institution's purpose; it must actively promote that purpose. The Court found that access provides such functional benefit to criminal trials because abuse is checked and the community's confidence in the judicial system is enhanced where the public has observed the process of justice being done. Public access to other governmental proceedings, Justice Brennan stated in Richmond, must serve analogous functions before openness would be constitutionally mandated. ${ }^{60}$

3. Compelling Interests. In light of the historical and functional support for open criminal trials, the Court in Globe held that any denial of access to criminal trials must be "necessitated by a compelling governmental interest" and be "narrowly tailored to serve that interest." familiar one in both first amendment ${ }^{63}$ and equal protection analysis, ${ }^{64}$ and underscores the significance of the right to attend crimi-

ss Id. at 569 (plurality opinion of Burger, C.J.), 595 (Brennan, J., concurring).

${ }^{s 6}$ Id. at 572 (plurality opinion of Burger, C.J.), 595 (Brennan, J., concurring).

87 Id. at 570 (plurality opinion of Burger, C.J.) (quoting C. GoEDE, A Foreigner's OpINION OF ENGLAND 214 (Horne trans. 1822)); see also Globe, 457 U.S. at 606.

${ }^{88}$ Richmond, 448 U.S. at 570 (plurality opinion of Burger, C.J.).

so Id. at 571 (plurality opinion of Burger, C.J.).

${ }^{60}$ See id. at 589 (Brennan, J., concurring) ("[T] specifics. . . . [W]hat is crucial . . . is whether access to a particular government process is important in terms of that very process.").

61457 U.S. at 606-07.

B2 Id. at 607 n.17.

63 For example, content-based restrictions on speech will be upheld only if "narrowly drawn to effectuate a compelling state interest." Perry Educ. Ass'n v. Perry Local Educators' Ass'n, 103 S. Ct. 948, 955 (1983) (citing Widmar v. Vincent, 454 U.S. 263, 269-70 (1981)).

64 In analyzing equal protection claims under the fourteenth amendment, the Supreme Court has held that a government classification that impinges on a fundamental right or interest or discriminates against a suspect class can be upheld only if justified by a "compelling state interest." See Roe v. Wade, 410 U.S. 113, 163-64 (1972) (state's interst in protecting fetal life becomes compelling only after the point at which the fetus is viable); Harper v. Virginia Bd. Of Elections, 383 U.S. 663, 670 (1966) (law restricting right to vote must be "closely scrutinized"); Korematsu v. United States, 323 U.S. 214, 216 (1944) (law restricting 
nal trials. ${ }^{65}$

When the state asserts a compelling interest to justify a denial of courtroom access, it in essence asserts that the harms that would result from disclosure outweigh the first amendment interest of the public in obtaining information about the judicial activities of the government. ${ }^{86}$ In Globe, the state argued that its interests in protecting minor victims of sex crimes from trauma justified excluding the public during the minor victims' testimony. ${ }^{67}$ The Court agreed that safeguarding the physical and psychological well-being of a minor might be a compelling state interest in some cases $^{68}$ but held that the Massachusetts legislature could not categorically require closure of all trials in which minor victims of sex offenses would appear as witnesses. Rather, the Court held, a trial court must make a case-by-case determination that "closure is necessary to protect" the welfare of the minor victim. ${ }^{69}$

The requirement in Globe of particularized determinations in individual cases has two aspects. First, no interest can be sufficiently compelling in the abstract to merit closure of every criminal trial in which it is implicated. The second aspect stems from the Court's requirement that denials of access be "narrowly tailored."70 A categorical rule of closure is by definition overbroad since "the circumstances of the particular case may affect the significance of the interest."

Finally, while a history of openness may alone suffice to support a constitutional right of access, a history of restriction will not

persons of Japanese descent from designated West Coast areas subject to "the most rigid scrutiny").

os Compare, for example, the "strict scrutiny" standard of the majority opinion in Globe with Chief Justice Burger's dissenting statement that "we . . . need only examine whether the restrictions imposed are reasonable and whether the interest of the Commonwealth override the very limited incidental effects on First Amendment rights." 457 U.S. at 616 (Burger, C.J., dissenting).

ob Some commentators, analogizing the right of access to the right to exercise other first amendment freedoms in public places, have argued that a presumptive right of access exists unless government can "prove functional incompatibility between access and the proceeding itself." J. Choper, Y. Kamisar \& L. Tribe, Richmond Newspapers: A Panel Discussion, in 2 The Supreme Court: Trends and Developments, 1979-1980, at 169, 170 (1981) (statement of L. Tribe); see Note, The First Amendment Right to Gather State-Held Information, 89 YALE L.J. 923, 936-38 (1980) (arguing that citizens should have a right of access to government information unless access is incompatible with the state's providing public services).

457 U.S. at 607.

ss Id. at 607-08.

68 Id. at 608; see id. at 611 n.27 ("[A] mandatory rule, requiring no particularized determinations in individual cases, is unconstitutional.").

${ }^{70}$ Id. at 606-07.

"Id. at 608. 
necessarily preclude a right of access. In Globe, the Court noted that the right of access to criminal trials is based only in part on the historic openness of such proceedings. "Whether the First Amendment right of access to criminal trials can be restricted in the context of any particular criminal trial ... depends not on the historical openness of that type of criminal trial but rather on the state interests assertedly supporting the restriction."72 This understanding of the use of history represents a significant departure from Chief Justice Burger's plurality opinion in Richmond. As the Chief Justice pointed out in Globe, Justice Brennan's majority opinion "ignores the weight of historical practice" by demanding that trials "involving sexual assaults against minors" be presumptively open. ${ }^{73}$ Although history may be used to assess the existence of a public right of access, the Globe majority held that any restrictions on that right cannot be justified solely by a tradition of closure.

\section{Applying the Globe Test to Civil Trials}

\section{A. The Historical Analysis}

Both historical and contemporary practice support the recognition of a constitutional right to attend civil trials. The early judicial system of England was not rigidly divided into civil and criminal matters as is the judicial system of today. There is no evidence of any real difference of authorities or procedure in the treatment of civil and criminal matters until the tenth century, at which time a number of serious public offenses were reserved for separate royal jurisdiction. ${ }^{74}$ The county and hundred courts, in which most litigants pressed their claims, were courts of general jurisdiction. ${ }^{75}$

72 Id. at 605 n.13.

7s Id. at 614 (Burger, C.J., dissenting).

74 F. Pollock \& F. Maitland, The History of English Law 38 (2d ed. 1898 \& photo reprint 1952). Although the king's courts in this manner wrested away the criminal jurisdiction of the local courts, the royal courts themselves exercised both a civil and a criminal jurisdiction. 1 W. Holdsworth, A History of ENGLISH LAw 40, 47 (4th ed. 1931). Royal jurisdiction over civil suits was supported by the fiction that "every cause for a civil action in the king's court was an offense against the king, punishable by amercement [forced pledge], if not by fine and imprisonment." 2 F. Pollock \& W. MAITLAND, supra, at 572; see also E. JENks, A ShORT HISTORY OF ENGLISH LAW 53 (4th ed. 1928) (discussing how the civil writ of trespass was founded on the fiction that any interference with possession was a breach of the king's peace).

${ }^{78} 1$ W. Holdsworth, supra note 74, at 9. At the time of the Norman Conquest all England was divided into either shires or counties. Id. at 6 . The latter in turn were divided into hundreds, wapentakes, or wards. Id. at 11. The high official of each hundred and county would preside over most civil and criminal suits; only if the litigants could not receive jus- 
Attendance at these courts was compulsory for all freemen. ${ }^{76}$ This tradition of public adjudication continued after the centralization of judicial power by the Norman kings ${ }^{77}$ and the growth of distinct procedures in civil and criminal suits. ${ }^{78}$ The itinerant royal justices, who administered the king's law throughout the land, ${ }^{78}$ would assemble large public gatherings ${ }^{80}$ for the hearing of both civil and criminal matters affecting the king's peace. ${ }^{81}$ Whatever the differences between civil and criminal procedure, ${ }^{82}$ public attendance at trial does not appear to have been one of them.

Given this unitary history, it is not surprising that early commentators either expressly or implicitly regarded civil trials as necessarily open to the public. Lord Coke speaks of openness as a characteristic feature of the king's courts generally, ${ }^{83}$ and Blackstone explicitly notes that the "presence of all mankind" is an integral aid to the factfinding process in private suits. ${ }^{84}$ More recent

tice in the local courts did they petition the king's courts. Id. at 9.

78 See Richmond, 448 U.S. at 565; 1 W. HoLdsworTh, supra note 74, at 12; 1 F. PoLLOCK \& W. MaITLAND, supra note 74, at 42-43.

73 For a discussion of this centralization, see supra note 74 .

78 For example, the Assize of Clarendon in 1166 established the jury of inquest, predecessor to the modern grand jury, as a special institution for the initiation and prosecution of certain crimes. T. PluckNeTt, A Concise History OF the Common Law 112, 428 (5th ed. 1956). The distinction between criminal and civil suits did not take hold until after the Norman Conquest. See id. at 422.

70 1 W. Holdsworth, supra note 74, at 49-51, 264-276; 1 F. Pollock \& W. Martland, supra note 74 , at $155-56$.

so At the Eyre of Kent in 1313, for example, Sir. H. de Staunton declared "the King's will was that all evil doers should be punished after their deserts, and that justice should be ministered indifferently to rich as to poor; and for the better accomplishing of this, he prayed the community of the county by their attendance there to lend him their aid . . .." 1 W. HoldsworTH, supra note 74 , at 268 . The Eyre was the most extensive and important of the commissions that empowered the royal justices to hear all pleas. Id. at 265 .

81 Id. at $50-51$.

s2 See T. PluckneTt, supra note 78, at 422-23.

ss [A]ll Causes ought to be heard, ordered, and determined before the judges of the kings courts openly in the King's Courts, whither all persons may resort; and in no chambers, or other private places. . . . Nay, that judge that ordereth or ruleth a cause in his chamber, though his order or rule be just, yet offendeth be the Law, (as here it appeareth) because he doth it not in Court.

E. Coke, The Second Part of the Institutes of the Lawes of England 103-04 (1642).

84 3 W. Blackstone, Commentaries on the Laws of England* 372-73. The remarks of Sir John Hawles, Solicitor-General in 1658, are in a similar vein: "[T]he reason that all trials are public, is, that any person may inform in point of fact, though not subpoen'd, that truth may be discovered in civil as well as criminal matters." Remarks upon Mr. Cornish's Trial in 11 T. Howell, Complete Collection of State Trials and Proceedings for High Treason and Other Crimes and Misdemeanors from the Earliest Period to the Year 1783, at 460 (London 1811). Other early commentators refer to the tradition of open trials in terms broad enough to suggest that civil as well as criminal trials were presumptively open. See Lilburne's Trial (1649), in 4 T. Howels, supra, at 1269, 1273 ("[A]ll courts of justice always 
cases and commentators note that public trials of both civil and criminal matters are a longstanding ${ }^{85}$ and conspicuous ${ }^{86}$ feature of English justice. In the words of one British case, "the inveterate rule is that justice shall be administered in open Court."

The English principle of openness was carried over into American colonial law. The 1677 Concessions and Agreements of West New Jersey, for example, provided that all citizens could freely attend "all publick courts of justice for tryals of causes, civil or criminal."88 A number of prominent state charters provided generally for "open" courts. ${ }^{89}$

Most states continue to guarantee open trials constitutionally or by statute..$^{90}$ In addition, the Federal Rules of Civil Procedure require that all trials "be conducted in open court" and that "the testimony of witnesses . . . be taken orally in open court."92 Finally, the Supreme Court has noted in dicta that civil trials were historically as open as criminal trials. ${ }^{93}$

ought to be free and open .....") (London 1809).

${ }^{86}$ Scott v. Scott, 1913 A.C. 417,440 ("[E]very Court of justice is open to every subject of the King. . . . [T] [Tis has been the rule . . . for some centuries . . . .").

86 E. Jenks \& D. Davies, The Book of English Law 72-73 (5th ed. 1953).

77 Scott v. Scott, 1913 A.C. 417, 445 (referring specifically to civil trials).

Concessions and Agreements of West New Jersey, ch. 23 (1677), reprinted in 1 B. Schwartz, The Roots of the BILL of Rights 129 (1980). This document was subtitled "The Charter or Fundamental Laws of West New Jersey, Agreed Upon," and has been hailed as an early example of the notion of a binding written Constitution. B. ScHWartz, supra, at 125.

8s See, e.g., Pennsylvania Frame of Government (1682), reprinted in B. Schwartz, supra note 88, at 140 (providing "that all courts shall be open"); Massachusetts Body of Liberties (1641), reprinted in B. SchwARTZ, supra note 88, at 80 (jurors "shall have libertie in open Court to advise with any man" (emphasis added)).

${ }^{\circ 0}$ For a list of state constitutional and statutory provisions regarding access, see $6 \mathrm{~J}$. Wigmore, Evidence $\S 1835$ n.2 (J. Chadbourn rev. ed. 1976); see also H. Cross, The PeoPLE's RIGHT To KNOW, 328-36, 337-47, 379-86 (1953). Some state guarantees of openness are broader than those of the United States Constitution. See, e.g., People v. Harris, 57 N.Y.2d $335,347,442$ N.E.2d 1205, 1210, 456 N.Y.S.2d 694, 699 (1982) (New York guarantee in criminal trials broader than federal); In re Westchester Rockland Newspapers v. Leggett, 48 N.Y.2d 430, 437-38, 399 N.E.2d 518, 521-22, 423 N.Y.S.2d 630, 634 (1982) (public trial guarantee under New York law may be asserted by public in civil as well as criminal trials).

92 Fed. R. Crv. P. 77(b); see also Tavoulareas v. Washington Post, 724 F.2d 1010, 101516 (D.C. Cir. 1984) (discussing the statutory presumptions of openness established by the federal rules), reh'g granted en banc, No. 83-1688 (March 15, 1984).

${ }^{82}$ FED. R. Civ. P. 43(a).

9s See Richmond, 448 U.S. at 580 n.17 (plurality opinion of Burger, C.J.), 599 (Stewart, J., concurring in the judgment); Gannett Co. v. DePasquale, 443 U.S. 368, 386 n.15 (Stewart, J.). But see Globe, 457 U.S. at 611 (O'Connor, J., concurring) ("I interpret neither Richmond Newspapers nor the Court's decision today to carry any implications outside the context of criminal trials."). 
B. The Functional Analysis

At first blush, the public interest in attending civil trials may seem less compelling than its interest in attending criminal trials. In criminal trials, the public is itself a party; if the defendant is convicted, the punishment will often be imprisonment at public expense. As noted by Chief Justice Burger, a shocking crime may trigger "a community reaction of outrage" which in turn calls for "open processes of justice." Civil trials, by contrast, frequently involve purely private disputes with little direct significance for anyone other than the parties. Even where the state is a party, a civil proceeding does not implicate the moral sanction of the public, and hence public concern and the need for openness may therefore be reduced.

To except civil suits from the open trial guarantee, however, would defeat the goals of informed public discussion and self-governance protected in Globe. ${ }^{95}$ Many civil suits concern the "vindication of constitutional or statutory policies" ${ }^{386}$ the proper resolution of which is as important to the public as is the punishment of serious crime. The federal government itself institutes more civil than criminal cases each year. ${ }^{97}$ These, as well as other, civil suits frequently involve "issues crucial to the public"98 such as school desegregation, ${ }^{89}$ prison reform, ${ }^{100}$ environmental pollution, ${ }^{101}$ and corporate misconduct. ${ }^{102}$ Moreover, the impact of such suits fre-

Richmond, 448 U.S. at 571.

9 Globe, 457 U.S. at 604-06.

*6 Chayes, The Role of the Judge in Public Law Litigation, 89 HARv. L. REv. 1281, 1284 (1976).

${ }^{97}$ In fiscal year 1982, for example, the federal government filed 48,868 civil complaints in federal court, but initiated only 32,682 criminal cases. AdMINISTRATIVE OfFIcE OR THE U.S. Courts, Annual Rsport of THE DiRzctor 4-5 (1982) [hereinafter cited as 1982 Annual REPORT]. The federal government was also a defendant in 26,905 civil suits during this period. Id. at 4.

os Brown \& Williamson Tobacco Corp. v. F.T.C., 710 F.2d 1165, 1179 (6th Cir. 1983).

" See Gannett Co. v. DePasquale, 443 U.S. 368, 386 n.15 (1979) (school desegregation cases, among others, given as examples of civil cases affecting interest of public at large).

${ }_{100}$ See, e.g., Newman v. Graddick, 696 F.2d 796, 800-01 (11th Cir. 1983) (court upholds first amendment right of access to post-trial and pre-trial proceedings in a civil class action challenging prison conditions in Alabama).

${ }^{101}$ See Chayes, supra note 96, at 1284.

102 See C. Stons, Where the Law Ends: The Social Control of Corporate Behavior 72 (1975) ("The public at large . . . [is] frustrated by apparent inability of the law to bring corporations under rein, awed by the magnitude of the problems, [and] baffled by the mystique that surrounds the inner workings and influence of the corporation . . . ."); see also Chayes, supra note 96 , at 1284 (listing securities fraud, antitrust, and other corporate suits as displaying in various degrees the features of public law litigation). 
quently extends beyond the parties to the public at large. ${ }^{103}$

Even where a particular civil suit does not directly affect the public at large, the judiciary remains a branch of government and its conduct of civil litigation is a matter "relating to the functioning of government,"104 a subject about which the public has a right to be informed. The Court in Globe did not predicate the public's right of access to criminal trials on its role as a party to the litigation. Instead, the Court emphasized that access to criminal trials fosters the "free discussion of governmental affairs"10s and protects the competence and integrity of the judicial process. ${ }^{108} \mathrm{~A}$ right of access to civil trials also serves this protective purpose. ${ }^{107}$ Because criminal cases currently account for less than half of the caseload in both federal and state courts, ${ }^{108}$ limiting the right of access to criminal cases would deprive the public of the opportunity to scrutinize much of the judicial process meaningfully, and the judicial system itself would suffer. As noted in Globe, public presence at trials aids accurate factfinding, ${ }^{109}$ fosters an appearance of fairness, ${ }^{110}$ and serves as a check on abuse. ${ }^{111}$ These benefits are not diminished simply because the underlying charge is civil and not criminal.

${ }^{103}$ See Chayes, supra note 96, at 1302 (relief in much public law litigation is not "confined in its impact to the immediate parties" but has "important consequences for many persons including absentees").

${ }^{104}$ Globe, 457 U.S. at 604 (quoting Richmond Newspapers, Inc. v. Virginia, 448 U.S. at $555,575(1980))$.

${ }^{105}$ Id. at 604 (quoting Mills v. Alabama, 384 U.S. 214, 218 (1966)).

${ }^{100} I d$. at 606.

${ }^{10 z}$ See Brown \& Williamson Tobacco Corp. v. F.T.C., 710 F.2d 1165, 1179 (6th Cir. 1983) ("In either the civil or the criminal courtroom, secrecy insulates the participants, masking impropriety, obscuring incompetence, and concealing corruption."); see also In re Iowa Freedom of Information Council, 724 F.2d 658, 661 (8th Cir. 1983) (extending the first amendment right of access to contempt proceedings, which are partly criminal and partly civil in nature, enhances and safeguards the quality of the fact-finding process).

${ }^{108}$ In federal court during fiscal year 1982, 206,193 civil cases were commenced compared to only 32,682 criminal cases. 1982 AnNuAl REPORT, supra note 97, at 4, 6. The most recent estimated figures for state courts show that in 1978, approximately $11,372,589$ civil cases were filed in all trial courts, compared to 8,804,329 criminal cases. NATIONAL CenTER for State Courts, State Court Caseload Statistics Annual Report 1978 at 38 (1983).

${ }^{109}$ Globe, 457 U.S. at 606; see also Richmond, 448 U.S. at 596 (Brennan, J., concurring) ("[M]istakes of fact in civil litigation may inflict costs upon others than the [parties].").

110 Globe, 457 U.S. at 606.

${ }^{111}$ Id.; see supra note 107. But see Rhinehart v. Seattle Times, 98 Wash. 2d 226, 253, 654 P.2d 673, 688 (1982) (suggesting that "the functioning of the adversary system plays an important role in avoiding abuses in civil proceedings" without indicating why the adversarial process functions less scrupulously in criminal than in civil trials), cert. granted, 104 S. Ct. 64 (1983). 


\section{Competing Interests}

Once one concludes, on the basis of both history and function, that civil trials are presumptively open, any denial of the right of access to such trials "must be necessitated by a compelling governmental interest," and be "narrowly tailored to serve that interest."112 At the very least, the state must show that the interests it seeks to protect through closure can be protected only by closure. ${ }^{113}$ Furthermore, the benefit that will accrue to the interest asserted must outweigh the infringement of the right of the public to have open courts. ${ }^{114}$ In Richmond, Justice Brennan pointed to national security"15 and Justice Stewart noted the "preservation of trade secrets"116 as two state interests that might justify public exclusion from portions of a trial in certain cases. Other potentially sufficient interests include the protection of juveniles ${ }^{117}$ and the preservation of personal privacy, ${ }^{118}$ interests that are frequently asserted to justify closure of civil or criminal trials. ${ }^{119}$ As the Court noted in Globe, however, even interests that are frequently compelling cannot support a categorical rule of closure. ${ }^{120}$ Given the presumption of access, assertions of these interests must be considered on a case-by-case basis to determine whether the asserted interest is truly compelling on the facts of a particular case and whether less restrictive alternatives exist. ${ }^{121}$

\section{A. The Interest in Protecting National Security}

The Supreme Court has consistently recognized that the gov-

112 Globe, 457 at 606-07.

11s $C f$. id. at 609 (Requiring the trial court to make case-by-case determinations "ensures that the constitutional right of the press and public to gain access to criminal trials will not be restricted except where necessary to protect the State's interest." (emphasis added)).

${ }^{114}$ Cf. id. at 606 (Only "weighty" justifications can override the presumption of openness in criminal trials.).

115 Richmond, 448 U.S. at 598 n. 24 (Brennan J., concurring).

116 Id. at 600 n.5 (Stewart, J., concurring in the judgment).

117 See Globe, 457 U.S. at 607 ("We agree with appellee that . . . safeguarding the physical and psychological well-being of a minor ... is a compelling [interest]."); Richmond, 448 U.S. at 600 n.5 (Stewart, J., concurring in the judgment) (The "sensibilities of a youthful prosecution witness . . . might justify [public] exclusion in a criminal trial for rape ....").

${ }^{118}$ See infra notes $200-219$ and accompanying text.

110 See 6 J. WIGMORE, supra note $90, \S 1835$, at 445 (noting that most states sanction closure in cases involving subjects such as rape or divorce or involving persons such as minors).

120457 U.S. at 611 n.27.

121 See supra notes 66-71 and accompanying text. 
ernment has a compelling interest in maintaining secret those matters whose disclosure would prejudice the national security. ${ }^{122}$ This interest permits the government to close trial $^{123}$ and pretrial ${ }^{124}$ proceedings over the objections of a criminal defendant, to punish its employees for violating contractual promises of secrecy, ${ }^{125}$ and to shield sensitive governmental information from production in civil trials. ${ }^{128}$

The government's privilege against production of documents containing national security information ensures that it will rarely need to move for trial closure to protect such information. ${ }^{127}$ Courts have traditionally given the "utmost deference"128 to assertions of this privilege, and have refused to allow even in camera examination of the evidence once, in the words of the Supreme Court in United States $v$. Reynolds, ${ }^{129}$ a "reasonable danger" of exposing national security information has been shown. ${ }^{130}$ Where a litigant seeks access to other types of sensitive governmental information, such as law enforcement information ${ }^{131}$ or confidential executive communications, ${ }^{132}$ the government retains only a "qualified" privilege against production of evidence. ${ }^{333}$ Under this

122 See Haig v. Agee, 453 U.S. 280, 307 (1981); Richmond Newspapers, Inc. v. Virginia, 448 U.S. 555, 598 n.24 (1980); Snepp v. United States, 444 U.S. 507, 509 n.3 (1980); United States v. Curtiss-Wright Export Corp., 299 U.S. 304, 320 (1936).

${ }^{123}$ See, e.g., United States ex rel. Lloyd v. Vincent, 520 F.2d 1272 (2d Cir.), cert. denied, 423 U.S. 937 (1975).

124 See, e.g., United States v. Bell, 464 F.2d 667 (2d Cir.), cert. denied, 409 U.S. 991 (1972).

${ }^{125}$ See Snepp v. United States, 444 U.S. 507 (1980).

128 See United States v. Reynolds, 345 U.S. 1 (1953).

${ }^{127}$ The national security or state secrets privilege can be broadly defined as a privilege that "protects information not officially disclosed to the public concerning the national defense or the international relations of the United States." 8 C. Wright \& A. MILLER, Federal Practice \& Procedure § 2019, at 158 (1970); see also National Lawyers Guild v. Attorney General, 96 F.R.D. 390, 401-02 (S.D.N.Y. 1982) (privilege limited to military matters, non-wartime foreign intelligence activities, covert intelligence sources, foreign liaison relationships, and intelligence collection methods).

${ }^{128}$ United States v. Nixon, 418 U.S. 683, 710 (1974); see Halkin v. Helms, 598 F.2d 1 (D.C. Cir. 1978).

128345 U.S. 1 (1953).

130 Id. at 10. For a persuasive argument that this standard insufficiently enforces statutory and constitutional constraints on executive activities, see Note, The Military and State Secrets Privilege: Protection for the National Security or Immunity for the Executive?, 91 YALE L.J. 570 (1982).

${ }^{131}$ See, e.g., Roviaro v. United States, 353 U.S. 53, 60-61 (1957) (informer's privilege); United States ex rel. Lloyd v. Vincent, 520 F.2d 1272, 1274-75 (2d Cir.) (same), cert. denied, 423 U.S. 937 (1975); Kinoy v. Mitchell, 67 F.R.D. 1, 5 (S.D.N.Y. 1975) (ongoing domestic security investigation).

132 See, e.g., United States v. Nixon, 418 U.S. 683, 706 (1974).

193 See Note, supra note 130, at 574-75. 
"qualified" privilege, a court must examine the information in camera and balance the public's interest in disclosure against the government's interest in secrecy before upholding the government's privilege. ${ }^{134}$

As a practical matter, resolution of the issue of privilege will determine the need or justification for trial closure in most cases. Where the privilege has been upheld, the unavailability of the evidence will render trial closure unnecessary. Conversely, judicial refusal to uphold the privilege ordinarily entails a finding that the state's interest in secrecy is less than compelling. ${ }^{135}$ As a practical matter, then, a colorable closure motion could arise only in two situations. First, where the court, in deciding a claim of qualified privilege, finds the state's interest in secrecy to be compelling but nonetheless outweighed by the litigant's need for production of relevant evidence, the state might seek trial closure as a secondary means of protecting its secrecy interests. Second, the government might agree to waive its evidentiary privileges on the condition that the trial portions containing such testimony be closed to all but the parties to the suit. ${ }^{136}$

Under Globe, trial closure in either situation would be justified only if "narrowly tailored" to further a "compelling" state interest. ${ }^{137}$ The court would need to inquire into the following factors: the extent to which the information is, in fact, secret, ${ }^{138}$ the degree to which the information concerns military or foreign intelligence matters whose secrecy has traditionally been deemed crucial to the public safety, ${ }^{139}$ the extent to which the release of the information would demonstrably impair the state's ability to function effectively, ${ }^{140}$ and whether a refusal to grant closure would impel the

1s4 See, e.g., United States v. Nixon, 418 U.S. 683, 711-12, 714-16 (1974).

198 For example, where the court applies the Reynolds "reasonable danger" standard, finds no "reasonable danger" that disclosure might harm the national security, and hence orders disclosure, see supra note 129-30 and accompanying text, the government's interest in secrecy would appear far too speculative to be deemed compelling. Cf. Globe, 457 U.S. at 609-10 (state's interest in encouraging minor victims of sex crimes to testify deemed insuffcient to justify categorical trial closure absent empirical support that closure in fact encouraged such testimony).

${ }^{136}$ See, e.g., Halpern v. United States, 258 F.2d 36, 44 (2d Cir. 1958) (closed proceedings preferable to denial of evidence in state secrets case).

137 Globe, 457 U.S. at 606-07.

138 Where the information has already been released to a nongovernmental litigant, for example, the government's diminished secrecy interest may no longer justify excluding the public from trial.

139 See, e.g., Snepp v. United States, 444 U.S. 507, 509 n.3 (1980); United States v. Reynolds, 345 U.S. 1, 10 (1953).

140 This inquiry is suggested by the requirement in both Globe and Richmond that or- 
government not to waive its evidentiary privilege. ${ }^{141}$ To ensure that this inquiry is meaningful, however, representatives of the press and public must be allowed to contest their exclusion..$^{142}$

\section{B. The Interest in Protecting Trade Secrets}

Closing trial for the protection of trade secrets is a well-established exception to the common law presumption of open trials. ${ }^{143}$ The first courts faced with this question justified closure on the grounds that certain types of commercial information ${ }^{144}$ were valuable only insofar as they were secret; ${ }^{145}$ forced exposure of the secrets at trial would therefore thwart the "justice" the court was supposed to provide. ${ }^{146}$ Later courts framed this reasoning in terms of adequacy of remedy:147 a plaintiff suing for trade secret misap-

ders permitting closure be based on particularized findings. See supra notes 70-7i and accompanying text.

141 This factor, of course, assumes that the harm to the public from closed proceedings would be far outweighed by the benefit to the individual litigant who would otherwise be denied justice. See Halpern v. United States, 258 F.2d 36, 44 (2d. Cir. 1958) (closed proceeding preferable to withholding needed information from litigant).

142 See Globe, 457 U.S. at 609 n.25.

14s See, e.g., Taylor Iron \& Steel Co. v. Nichols, 73 N.J. Eq. 684, 690, 69 A. 186, 188 (1908) (in camera hearing allowed during discussion of manufacturing process); Kaumagraph Co. v. Stampagraph Co., 197 A.D. 66, 73, 188 N.Y.S. 678, 683 (1921), aff'd, 235 N.Y. 1, 138 N.E. 485 (1923) (same); E. JENKs \& D. DAVIEs, supra note 86, at 72-73 (cases involving trade secrets a recognized exception to the rule of open court).

${ }^{144}$ Most of the older cases concern mechanical or chemical processes. See, e.g., Herold v. Herold China \& Pottery Co., 257 F. 911 (6th Cir. 1919) (formulas for making fine grade porcelain ware); Masland v. E.I. DuPont de Nemours Powder Co., 224 F. 689 (3d Cir. 1915) (processes used in making artificial leather), rev'd on other grounds, 244 U.S. 100 (1917); Pomeroy Ink v. Pomeroy, 77 N.J. Eq. 293, 78 A. 698 (1910) (formulas for making ink); Taylor Iron \& Steel Co. v. Nichols, 73 N.J. Eq. 684, 69 A. 186 (1908) (process for molding steel); Kaumagraph v. Stampagraph Co, 197 A.D. 66, 188 N.Y.S. 678, 683 (1921) (heat-process for printing fabric designs), aff'd, 235 N.Y. 1, 138 N.E. 485 (1923); Amber Size \& Chemical Co. v. Menzel, [1913] $2 \mathrm{Ch}$. 239 (secret mixture for amber size and grain size manufacturing); Badische Arnilin \& Soda Fabrik v. Levinstein 24 Ch. D. 156, 169 (1881) (considered question of in camera protection for formula dyes to be one of first impression). Customer lists were also occasionally protected in this way. See, e.g., Witkop \& Holmes Co. v. Boyce, 61 Misc. 126, 130, 112 N.Y.S. 874, 877, (allowing customer lists to be treated as trade secrets), aff'd, 131 A.D. 922, 115 N.Y.S. 1150 (1908); see also infra notes 150-52 and accompanying text.

${ }_{145}$ "The property [interest] in a secret process is the power to make use of it to the exclusion of the world. If the world knows the process, then the property [interest] disappears." State ex rel. Ampco Metal v. O'Neill, 273 Wis. 530, 533. 78 N.W.2d 921, 923 (1956) (quoting Cincinnati Bell Foundry Co. v. Dodds, 10 Ohio Dec. Reprint 154 (1887)).

${ }^{140}$ Scott v. Scott, 1913 A.C. 417, 443 ("[I]t would be the height of absurdity as well as of injustice to allow a trial at law to protect [a secret] to be made the instrument of destroying the very thing it was intended to protect."); see also Badische Arnilin \& Soda Fabrik v. Levinstein, 24 Ch. D. 156, 169 (1881).

${ }^{147}$ See State ex rel. Ampco Metal v. O'Neill, 273 Wis. 530, 540, 78 N.W.2d 921, 927 
propriation would be left with no effective remedy against persons other than the defendant if the court disclosed the secret to the public.

Because trade secrets cannot be preserved and hence justice cannot be done in certain cases without trial closure, the protection of such secrets may constitute a "compelling interest" sufficient to justify at least partial closure of civil trials. ${ }^{148}$ Given the Globe requirement that any orders restricting access be "narrowly tailored,"148 however, it is important to scrutinize claims of trade secrets strictly in order to avoid closing trials where disclosure of the purportedly secret information would not work the competitive harms trade secret law is intended to prevent.

The notion of legally protected trade secrets developed in the private law context to remedy the unjust enrichment and competitive harm resulting from a defendant's misappropriation of commercially valuable information through theft or breach of confidence. ${ }^{100}$ Early decisions addressing the protection of trade secrets often distinguished between process-related information and information regarding "collateral matters of business confidentiality such as pricing and sales volume data, sources of supply and customer lists."161 Many early cases limited the term "trade secrets" to the former category. ${ }^{152}$ Recognizing that other forms of informa-

(1956).

${ }^{24}$ While the broad principle is that the Courts of this country must, as between parties, administer justice in public, this principle is subject to apparent exceptions. . . . But the exceptions are themselves the outcome of a yet more fundamental principle that the chief objects of Courts of justice must be to secure that justice is done. . . . [I]t may well be that justice could not be done at all [in trade secret cases] if it had to be done in public.

Scott v. Scott, 1913 A.C. $417,437$.

140 457 U.S. at 606-07; see supra notes $61-73$ and accompanying text.

${ }^{180}$ Connelly, Secrets and Smokescreens: A Legal and Economic Analysis of Government Disclosures of Business Data, 1981 Wis. L. REv. 207, 230.

$13 \mathrm{I}$ Id.

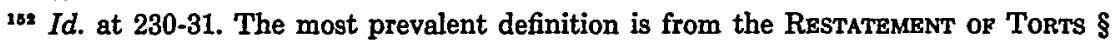
757b (1939): "A trade secret may consist of any formula, pattern, device or compilation of information which is used in one's business, and which gives him an opportunity to obtain an advantage over competitors who do not know or use it." For cases allowing confidential business data such as customer lists to be treated as trade secrets, see Arnold's Ice Cream Co. v. Carlson, 330 F. Supp. 1185 (E.D.N.Y. 1971); Servisco. v. Morreale, 312 F. Supp. 103 (E.D. La. 1970); Inland Rubber Corp. v. Triple A Tire Service, Inc., 210 F. Supp. 880 (S.D.N.Y. 1962); Erone Corp. v. Skouras Theatres Corp., 22 F.R.D. 494 (S.D.N.Y. 1958); Town \& Country House \& Home Service, Inc. v. Newberry, 3 N.Y.2d 554, 170 N.Y.S.2d 328, 147 N.E.2d 724 (1958); National Starch Prods., Inc. v. Polymer Indus., 273 A.D. 732, 79 N.Y.S.2d 357 (1948); People's Coat, Apron \& Towel Supply Co. v. Light, 171 A.D. 671, aff'd, 224 N.Y. 727, 121 N.E. 886 (1918); Cupid Diaper Service v. Adelman, 27 Misc. 2d 1095, 211 N.Y.S.2d 813 (Sup. Ct. 1961). Prior to 1970, FED. R. CIv. P. 30(b), the predecessor of the 
tion such as customer lists also involve significant investments of time and effort and that allowing competitors to misappropriate such information would work the same kind of competitive unfairness as does release of process-related information, courts have broadened the definition of trade secrets to include any commercial information used to obtain an advantage over competitors. ${ }^{163}$

In formulating trade-secret doctrines, courts and legislatures have attempted to balance the interest in preventing unfair competition against the general interest of the public in the free flow of information. ${ }^{154}$ This latter interest is particularly important where a trade secret is involved in a civil or criminal trial. Therefore, courts must be vigilant in ensuring that information that a party seeks to exclude from public view through trial closure is, indeed, a 'legitimate trade secret.

Two recent suits illustrate the problems of lax application of the trade secrets exception to court access. In Standard \& Poor's Corp. v. Commodity Exchange, ${ }^{165}$ information regarding Standard \& Poor's (S \& P's) 500 Stock Index was held to be a "business confidence," entitling S \& $\mathrm{P}$ to close those portions of the trial and to seal those portions of the transcript that described the procedures used in computing the index. ${ }^{158}$ Assuming, but not declaring, the existence of a first amendment right to attend civil trials, ${ }^{107}$ the judge nonetheless relied on counsel's representation without conducting his own factual examination ${ }^{168}$ and without giving the pub-

present Rule 26(b), afforded protection from disclosure only to "secret processes, developments, or research" and did not protect trade secrets or other confidential business information. See Zenith Radio Corp. v. Matsushita Elec. Indus. Co., 529 F. Supp. 866, 890 n.41 (E.D. Pa. 1981). Nonetheless, federal courts protected such information "by analogizing trade secrets and confidential commercial information to the types of information explicitly covered by Rule 30(b)." Id.

${ }_{135}$ Public Citizen Health Research Group. v. F.D.A., 704 F.2d 1280, 1289 n.25 (D.C. Cir. 1983) (quoting McGarity \& Shapiro, The Trade Secret Status of Health and Safety Testing Information: Reforming Agency Disclosure Policies, 93 HARv. L. REv. 837, 863 (1980)).

${ }^{154}$ For a discussion of the public interest in the disclosure of business information, see Connelly, supra note 150 , at $221-229$.

18s 541 F. Supp. 1273 (S.D.N.Y. 1982).

${ }^{185}$ Id. at 1275, 1277-78. The case arose from a civil proceeding brought by $\mathrm{S} \& \mathrm{P}$ against Commodity Exchange, Inc. for trademark infringement. S \& $\mathrm{P}$ was allowed to introduce into evidence confidential internal management procedures regarding the preparation of its $\mathbf{5 0 0}$ Stock Index in closed session. Commodity News Service then instituted suit to gain access to the transcripts of the closed proceeding, arguing that the procedures constituted matters of "business confidentiality," which were insufficient to outweigh the constitutional right of access. Id. at 1274.

${ }^{157}$ Id. at $1275-76$.

158 Id. at 1277-78. 
lic or press an opportunity to contest their exclusion. ${ }^{159}$

In Tavoulareas $v$. The Washington Post Co., ${ }^{160}$ the District Court for the District of Columbia had extended to the $\operatorname{trial}^{161}$ a pretrial protective order governing confidential corporate documents of intervenor Mobil Oil Corporation, ${ }^{162}$ thereby withholding the documents themselves from public view, ${ }^{163}$ and permitted Mobil to excise portions of the trial transcript as "confidential" before its release to the public. ${ }^{184}$ Although it acknowledged a possible first amendment right to gather news, the court did not consider the first amendment in its decision, nor did it disclose the reasoning behind its conclusion. ${ }^{165}$ Rather, the court in effect delegated the task of deciding what documents merited secrecy to the party resisting disclosure.

In both Standard \& Poors and Tavoulareas the court failed to make the particularized inquiry that is a necessary prerequisite to ordering trial closure. ${ }^{168} \mathrm{~A}$ party in a law suit may have any number of reason for not wanting information publicly released besides that information's commercial value. The information might embarrass individual employees, officers, directors, or shareholders, or damage the reputation of the firm by casting doubt upon their abilities, scruples, or actions; none of this information, however, falls within the notion of a trade secret, and a party ought not,

180 Cf. Globe, 457 U.S. at 609 n.25 ("[F]or a case-by-case approach to be meaningful, representatives of the press and general public 'must be given an opportunity to be heard on the question of their exclusion.' (quoting Gannett Co. v. DePasquale, 443 U.S. 368, 401 (1979) (Powell, J., concurring))).

180 Nos. 80-3032, 80-2387 (D.D.C., filed Nov. 25, 1980). Tavoulareas was a libel suit filed by William Tavoulareas, president of Mobil Oil, and his son, Peter, against The Washington Post. The jury verdict for the plaintiffs was overturned post-trial. See Tavoulareas v. The Washington Post Co., 567 F. Supp. 651 (D.D.C. 1983). The discussion in text concerns pretrial orders limiting press access to documents used at trial.

${ }_{101}$ Tavoulareas v. The Washington Post Co., Nos. 80-2387, $80-3032$ at 3 (D.D.C. July 8 , 1982) (order granting extension of protective order to trial) (on file with The University of Chicago Law Review). On June 21, 1983, the district court unsealed the depositions subject to this order, a decision that was reversed on appeal. See Tavoulareas v. The Washington Post Co., 724 F.2d 1010, 1015 (D.C. Cir.), reh'g granted en banc, No. 83-1688 (March 15, 1984).

${ }_{162}$ Tavoulareas v. Piro, 93 F.R.D. 24, $28-30$ (D.D.C. 1981) (pretrial protective order issued).

10s Those documents not used at trial were recently resealed. See Tavoulareas v. The Washington Post Co., 724 F.2d 1010, 1012 (D.C. Cir.), reh'g granted en banc, No. 83-1688 (March 15, 1984).

184 Tavoulareas v. The Washington Post Co., Nos. 80-2387, 80-3032, at 3 (D.D.C. July 8, 1982) (order permitting excision of confidential parts of trial transcript) (on file with The University of Chicago Law Review).

${ }^{168}$ Id.

${ }^{166}$ For the Court's requirement as stated in Globe, see 457 U.S. at 608. 
merely by intoning the words "trade secret," to be able to prevent public disclosure of the information. ${ }^{167}$

As a general matter, courts should examine in camera ${ }^{168}$ the particular information for which a trade secret exception is claimed. Furthermore, since the adverse party in the lawsuit is unlikely to have any particular interest in vindicating the public's right of access, representatives of the press or the public should be permitted to intervene to contest the trade secret exception claim.

\section{The Interest in Protecting Juveniles}

All states have statutorily created juvenile or family courts ${ }^{169}$ which generally exercise jurisdiction over delinquent, "incorrigible," and neglected children. ${ }^{170}$ The subject matter jurisdiction of these courts extends beyond juvenile conduct that would be criminal if committed by an adult, ${ }^{171}$ to noncriminal misbehavior of juveniles, such as truancy, ${ }^{172}$ running away, ${ }^{173}$ "unruly" or "incorri-

167 See In re Iowa Freedom of Information Council, 724 F.2d 658, 662 (8th Cir. 1983) (injuries to competitive position flowing "from customer or employee disgruntlement or from the embarrassing publicity attendant upon public revelations" of unethical or illegal conduct are subject to disclosure; Brown \& Williamson Tobacco Corp. v. F.T.C., 710 F.2d 1165, 1179 (6th Cir. 1983): ("Simply showing that the information would harm the company's reputation is not sufficient to overcome the strong common law presumption in favor of public access to court proceedings and records.").

16s See In re Iowa Freedom of Information Counsel, 724 F.2d 658, 662 (8th Cir. 1983) (courts should hold closure hearings in camera in order to protect the alleged trade secrets, but the portions of those hearings conducted in camera should be as limited as possible). Although the district court in Iowa Freedom of Information Council concluded that the alleged items were in fact trade secrets on the representation of counsel, the appellate court warned that more than mere representations must ordinarily be made. Id. at 663 .

${ }^{163}$ For a list of such state courts, see J. WrGMORE, supra note $90, \S 1835(2)$ n.3.

170 See 47 AM. JuR. 2D Juvenile Courts $\$$ 23, 24 (1969).

371 Opfice of Juvenile Justice and Delinquency Prevention, U.S. Dept of Justice, Standards for the AdMinistration of JUVEnILE Justice: Report of the National AdVI-

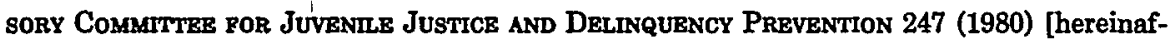
ter cited as STANDARDs]. All states define delinquency to include conduct that would be a felony if committed by an adult, but some states distinguish between delinquent and "miscreant," or misdemeanor, offenses. Other states specifically exempt violations of municipal or other local ordinances from their definitions of "delinquency." Id. Delinquency adjudications in juvenile court resemble criminal trials, and will therefore not be discussed in this comment. For an excellent treatment of access to juvenile delinquency proceedings, see Note, The Public Right of Access to Juvenile Delinquency Hearings, 81 MrcH. L. REv. 1540 (1983) (arguing that the Globe standard should be extended to provide a public right of access to juvenile delinquency proceedings). To the extent that any juvenile proceeding resembles a criminal trial, the argument for a comprehensive first amendment public right of access is that much more clearly mandated by Globe and Richmond.

172 Truancy is included within the jurisdiction of the juvenile or family courts of 39 states and of the District of Columbia. STANDARDs, supra note 171, at 251.

173 All states currently provide for jurisdiction over runaways, either specifically or 
gible" behavior, ${ }^{174}$ and to parental neglect and abuse. ${ }^{175}$ The nondelinquency proceedings in juvenile court are generally civil in nature since they do not involve otherwise criminal conduct and since the state's role is to attempt to assist the juvenile in resolving his status rather than to attempt to convict him. ${ }^{178}$

The majority of juvenile courts are governed by statutory requirements of secrecy in their proceedings and records. ${ }^{177}$ The Supreme Court has held that states should strive to create juvenile proceedings that are "intimate, informal [and] protective,"178 and exclusion of the public from the proceedings has been justified as serving the best interests of the child.179 In excluding the public, the state attempts to prevent immediate trauma to the child and to protect the child's reputation against the lifelong stigma of delinquency or dependency. ${ }^{180}$ Furthermore, informal and closed pro-

under the provisions covering children "beyond parental control." Id.

${ }^{174}$ Some states entertain jurisdiction over disobedience to parental demands. Id. Most states include incorrigibility in one form or another within the jurisdiction of the family court. Id. at 252.

${ }^{178}$ Most states provide jurisdiction over a child in neglect and abuse cases without requiring that harm or a threat of imminent harm be shown in order for the matter to be cognizable in the family court. Id. A few states have statutes addressing the emotional neglect of a child, and Florida, South Carolina and Utah authorize judicial intervention for failure of a child's parents to provide psychiatric help. Id. at 256. Most states provide for jurisdiction in cases of destitution or make no exception in "failure to provide" statutes for lack of financial resources. Id. A number of states currently include placement of a child in unlicensed facilities as a ground for declaring the child neglected or abused. Id.

176 About $15 \%$ of the cases filed in American juvenile and family courts are based on "status offenses" such as truancy, running away, or incorrigibility. More than sixty-six percent of noncriminal misbehavior referrals are handled by intake personnel without filing a petition. Nearly one third of all juveniles charged with noncriminal misbehavior spend time in a detention facility and about five percent of those adjudicated are sent to juvenile institutions. Id. at 249-50 (citing D. SMrth, T. Finnegan, H. SNYder \& J. CorbetT, Delinquency 1975: United States Estimates of Cases Processed with Juvenlle JuRisdiction (1975)).

${ }^{177}$ A list of these statutes is provided in Note, supra note 171 , at 1540 n.3.

17e McKeiver v. Pennsylvania, 403 U.S. 528, 545 (1971). In McKeiver, the Court promoted this version of juvenile proceedings by denying the right to a jury trial in delinquency proceedings. But see In re Gault, 387 U.S. 1, 25-31 (1967) (arguing that informality of juvenile proceedings is no justification for procedural arbitrariness).

170 J. WIGMore, supra note 90, § 1835(2); see also In re Gault, 387 U.S. 1, 24-25 (1967) (discussing claim of confidentiality in juvenile proceedings).

${ }^{180}$ In his dissent in Globe, Chief Justice Burger decried as "paradoxical" the fact that, under Globe, a minor victim of a sexual crime cannot be protected from publicity while a minor offender can be protected under most state statutes. 457 U.S. at 612; see also Note, supra note 171, at 1540 (arguing that the "paradox" could be resolved by permitting a public right of access to juvenile delinquency proceedings). While it is true that the victim has done nothing to deserve any trauma, and therefore merits great protection, the victim, unlike the offender, usually will not be stigmatized by what has happened through continued involvement with the state as a "delinquent" or "ward of the court." Because the purpose of the juvenile courts is supervision rather than punishment for the acts of the juvenile's im- 
ceedings are also considered conducive to eliciting the truth from the juvenile who might be frightened, or, conversely, overly impressed, by more formal and public proceedings. ${ }^{181}$

Since Richmond and Globe, however, secrecy requirements in juvenile courts, at least where those courts are involved in delinquency proceedings, have been challenged as violating the first amendment right of access. ${ }^{182}$ Juvenile proceedings, whether they concern quasi-criminal or status offenses, are functionally similar to trials and are subject to the same sort of procedural abuses that openness in criminal trials forestalls. ${ }^{183}$ The Supreme Court itself has noted the possibility of juvenile court misconduct: "Too often the juvenile court judge falls far short of that 'stalwart, protective and communicating figure the system envisaged."184 Justice Brennan has also noted that while the juvenile courts are not bound by all forms of due process, some forms are needed to protect the juvenile "against misuse of the judicial process."185 Without assurances that family court judges adjudicate with "parental" concern, the public cannot trust in the quality of mandatorily closed proceedings, and a check on the system is necessary. ${ }^{186}$

maturity, the courts have an obligation to reduce this inevitable stigmatization as much as possible. Closure, therefore, to the extent that it is justified in any case because of the involvement of a juvenile, may be more justifiable when that juvenile is an offender.

${ }_{181}$ See In re Robert M., 109 Misc. 2d 427, 430 n.8, 439 N.Y.S.2d 986, 989 n.8 (N.Y. Fam. Ct. 1981); J. WIGMORE, supra note 90, § 1835(2).

${ }^{102}$ In In re Robert M., 109 Misc. 2d 427, 439 N.Y.S.2d 986 (N.Y. Fam. Ct. 1981), the New York trial court held that a state statute which provided for selective exclusion of the public from juvenile delinquency proceedings was constitutional under Richmond because of the special state interests in preventing trauma and stigma of juveniles. The New York statute permits a court to allow press access to juvenile proceedings only after the court considers the likelihood of disruption, any objections of parties, the media's agreement to avoid identification of parties or witnesses, the media's past behavior with respect to the privacy of the proceedings, and the need for the orderly administration of justice. N.Y. FAM. Cr. ACT \& 212 (McKinney 1975). The court, in upholding a denial of access, noted the Supreme Court's recent concern for juvenile court privacy and the particular need for such privacy in this case, which involved a nine-year-old who had committed acts that would otherwise be a crime. 109 Misc. 2d at 429-30, 439 N.Y.S.2d at 988-89.

18 J. WIGMORE, supra note $90, \S 1835$ (2) ("No court of justice can afford habitually to conduct its proceedings strictly in private. . . The tendency to undue privacy should be checked.").

184 McKeiver v. Pennsylvania, 403 U.S. 528, 544 (1970); see id. at 544 n.4 ("A recent study of juvenile court judges . . . revealed that half had not received undergraduate degrees; a fifth had received no college education at all; and a fifth were not members of the bar." (quoting President's Commission on Law Enrorcement \& Administration of Juvenile Justice, Task Force Raport: Juvenile Deginquency and Youth Crume 7 (1967))).

${ }^{185}$ Id. at 556 (Brennan, J., concurring in part and dissenting in part).

${ }^{188}$ As one commentator has noted, "legal standards must be designed for a world that includes both good judges and bad judges." F. Zimring, The Changing Legal Wordd of Adolescence 71 (1982). 
Moreover, juvenile proceedings adjudicating cases of noncriminal misbehavior, neglect, or abuse raise issues of substantive concern to the community at large. The proper scope of jurisdiction over noncriminal behavior is "one of the most hotly debated issues in juvenile justice today."187 The intervention of the state into family life, whether on the grounds of neglect, abuse, incorrigibility, or delinquency, is a constant source of tension in society, yet the standards governing the threshold of intervention are still largely undefined..$^{188}$ Because adolescence is, as one perceptive commentator has put it, "a period of semi-autonomy, it places special burdens on legal reasoning and public choice."188 The public can choose effective means of assisting those juveniles "guilty" of status offenses only if it is aware of the way in which these juveniles are treated in family courts. Greater access to the family courts, guaranteed by tests which limit judicial discretion to exclude members of the press and public arbitrarily, will help inform the public's choice regarding the treatment of juvenile status offenders.

The Globe test can be applied in those juvenile proceedings that adjudicate noncriminal misbehavior, neglect, and abuse as well as it can be applied to delinquency cases. As suggested in Globe, mandatory closure of all juvenile proceedings should be regarded as impermissible. ${ }^{190}$ State statutes that permit closure are constitutional only insofar as they entail a rebuttable presumption of public access to the proceedings ${ }^{191}$ and permit closure only after

${ }^{187}$ Standards, supra note 171, at 249. Compare Institute of Judicial Administration/American Bar Association Jornt Commission on Juventle Justice Standards, StanDards Relating to Noncriminal Misbehavior (1977) (arguing that a system which imposes the same sanctions for parental defiance as for armed robbery is unfair), with Arthur, Status Offenders Need Help Too, 26 Juv. JUST. 3, 5 (1975) (arguing that noncriminal misbehavior indicates that more serious trouble may be approaching and that the family court may be the only place to prevent future crimes from occurring).

188 See generally Wald, State Intervention on Behalf of "Neglected" Children: A Search for Realistic Standards, 27 Stan. L. REv. 985, 1000-01 (1975) (Most statutes fail to define "neglect" and therefore allow intervention into family life without the need to do so.).

For examples of controversial decisions regarding adolescent rights, see Akron v. Akron Center for Reproductive Health, Inc., 103 S. Ct. 2481 (1983) (holding unconstitutional a state law which required, inter alia, that all minors under the age of 15 obtain the consent of the parents before obtaining an abortion); Carey v. Population Servs. Int'I, 431 U.S. 678 (1976) (striking down a New York law prohibiting the distribution of nonprescription contraceptives to children under 16 years of age).

189 F. ZIMRING, supra note 186, at $\mathrm{x}$ (1982). For the author's brief discussion of status offenders, see id. at $69-75$.

190 See Globe, 457 U.S. at 610-11 n.27 (rule of mandatory closure respecting the testimony of minor sex victims constitutionally infirm).

191 Id. at 610 ; cf. id. at $608 \mathrm{n} .22$ (noting that no other state has a mandatory closure rule 
the judge has considered the public's constitutional right of access and articulated a compelling state interest necessitating denial of that right. ${ }^{192}$ Even in cases that meet this standard, the proceedings should be closed only to the extent necessary to preserve the compelling state interest. ${ }^{103}$

Factors that a state might successfully assert as supporting a compelling interest in trial closure include the extreme youth of the child, ${ }^{184}$ proven psychological problems that would be exacerbated by public exposure, ${ }^{195}$ or sensational facts that might subject the juvenile to acute and long-lived publicity. ${ }^{196}$ The focus of the court should be on the protection of the particular child, not protection of the child's family, ${ }^{197}$ the prior conduct of the press, ${ }^{198}$ nor the threat of disruption to the proceedings. ${ }^{199}$ These concerns do not address the purpose of secret proceedings, which is to promote the best interests of the child, and therefore are not sufficiently compelling to deny access.

\section{The Interest in Protecting Privacy}

Mandating public access to civil trials subjects civil litigants to a waiver of their right to privacy whenever they seek to pursue a legal remedy. ${ }^{200}$ Divorce suits are discussed here as a dramatic ex-

for the testimony of minor victims).

192 Id. at 610-11 n.27 (requiring particularized determinations in individual cases); see also Richmond, 448 U.S. at 581 (plurality opinion of Burger, C.J.) ("Absent an overriding interest articulated in findings the trial of a criminal case must be open to the public.").

193 Globe, 457 U.S. at 606-07.

194 See, e.g., id. at 608; In re Robert M., 109 Misc. 2d. 427, 432, 439 N.Y.S.2d 986, 990 (1981).

198 See, e.g., Globe, 457 U.S. at 608.

190 The gist of this factor is that if the court perceives a likelihood of notorious publicity, and believes that sparing the juvenile from it will deter him from committing more criminal acts, then the state may have a compelling interest in closing that juvenile's trial.

${ }^{197}$ Both the New York court in In re Robert M., 109 Misc. 2d 427, 432, 439 N.Y.S.2d 986, 990 (N.Y. Fam. Ct. 1981), and the Supreme Court in Globe, 457 U.S. at 608, include the interests of the parents and relatives of the juvenile among the factors to be considered in ruling on motions for closure. The reasoning behind this consideration rests on a presumption that the child and the family are such an integral unit that, in order to promote the best interest of the child, the parents' interest in secrecy must also be protected. Yet, this presumption may not hold in every case. Particularly where the child will no longer live with the parents after the adjudication, the parents' interest in secrecy does not seem sufficiently compelling, at least alone, to deny the public access to the proceeding.

188 The court in In re Robert M., 109 Misc. 2d. 427, 429, 439 N.Y.S.2d 986, 989 (N.Y. Fam. Ct. 1981), relied in part on prior press actions in closing the trial.

199 See id. at 429,439 N.Y.S.2d at 988.

200 For a discussion of the effect of a right of access to civil trials on individual privacy interests, see Note, supra note 8 , at 311-14. 
ample of the humiliation and embarrassment faced by litigants embroiled in legal disputes over personal matters. ${ }^{201}$ Some states, out of concern for these privacy interests and in an effort to preserve public morals, have provided by statute ${ }^{202}$ or judicial deci$\operatorname{sion}^{203}$ that public access to divorce proceedings may be denied.

The majority of courts ${ }^{204}$ have rejected this view. Such courts have held that humiliation and embarrassment are insufficient interests to outweigh the benefits of open trials:

The hearing of a case in public may be, and often is, no doubt, painful, humiliating or deterrent to both parties and witnesses, . . . but all this is endured because it is felt that in the public trial is to be found, on the whole, the best security for the pure, impartial and efficient administration of justice, the best means for winning for it public confidence and respect. ${ }^{20 s}$

Courts have also rejected the argument that divorce trials may be closed to protect public morals, on the ground that it is "better for the public interest" to conduct potentially scandalous trials "in the presence of responsible portions of the community."208 The public has an interest in open courts, despite the contrary preferences of litigants; courts "are not to be considered as the private domain of any person or group of persons."20z

201 See, e.g., In re Shortridge, 99 Cal. 526, 34 P. 227 (1893); State ex rel. English v. McCrary, 328 So. 2d 257 (Fla. Dist. Ct. App. 1976), aff'd, 348 So. 2d 293 (Fla. 1977); State ex rel. Gore Newspapers Co. v. Tyson, 313 So. $2 d 777$ (Fla. Dist. Ct. App. 1975), overruled, English v. McCrary, 348 So. $2 d 293$ (Fla. 1977). While disclosure of sexually intimate matters may of course arise in non-divorce litigation, see, e.g., State v. Schmit, $273 \mathrm{Minn}$. 78, 139 N.W.2d 800 (1966) (criminal trial for sodomy), those cases will not be discussed here.

${ }^{202}$ See, e.g., Idaho R. Crv. P. 77(b) (Supp. 1983); Iowa Codr AnN. \& 598.8 (West 1981); N.Y. Jud. LAw \& 4 (McKinney 1983); UTAH CODB ANN. \& 78-7-4 (1953). For a fuller listing, see J. WIGMORE, supra note 90, § 1835(1) n.2.

${ }^{203}$ See, e.g., State ex rel. English v. McCrary, 328 So. 2d 257, 263 (Fla. Dist. Ct. App. 1976), aff'd., 348 So. 2 d 293 (Fla. 1977).

${ }_{204}$ In re Shortridge, 99 Cal. 526, 34 P. 227 (1893); State ex rel. Gore Newspapers Co. v. Tyson, 313 So. 2d 777 (Fla. Dist. Ct. App. 1975), overruled, English v. McCrary, 348 So. 2d 293 (Fla. 1979); McPherson v. McPherson, 1936 A.C. 177 (P.C. 1935) (Alta.); Scott v. Scott, 1913 A.C. 417.

${ }^{203}$ Scott v. Scott, 1913 A.C. $417,463$.

206 Williamson v. Lacy, 86 Me. 80, 81, 29 A. 943, 944 (1893) (action for trespass brought against a magistrate who had plaintiff removed from a trial involving adultery). In State v. Schmit, 273 Minn. 78, 139 N.W.2d 800 (1966), the Minnesota Supreme Court reached a similar conclusion with respect to the disclosure, in a criminal trial, of sexual practices: "'[T] cludes a determination that all members of the public. . . may reasonably be excluded from the trial of a sexual offense upon the ground of public morals.' "Id. at 85, 139 N.W.2d at 805 (quoting United States v. Kobli, 172 F.2d 919, 923 (3d Cir. 1949) (en banc)).

${ }^{207}$ State ex rel. Gore Newspapers Co. v. Tyson, 313 So. 2d 777, 784 (Fla. Dist. Ct. App. 
According to one early court, to hold embarrassment sufficient reason to close trials would necessitate the closure of all trials, since trials are inevitably embarrassing to someone. ${ }^{208}$ The same court rejected the argument that fear of publicity would deter timid litigants and witnesses from appearing in court, arguing that publicity is recognized as a necessary part of the process. ${ }^{200}$ Even though a constitutionally rooted right in avoiding public disclosure of personal matters has been recognized, ${ }^{210}$ it is unlikely that the assertion of privacy can be sufficiently "compelling" to close divorce proceedings. ${ }^{211}$ Under Richmond and Globe, the mere fact that a constitutional interest is threatened by courtroom publicity does not warrant a closed trial. ${ }^{212}$ Rather, any denial of access must be necessitated by a governmental interest shown to be "compelling" under the facts of the case at hand. ${ }^{213}$ Absent evidence that public proceedings would subject the civil litigant to physical ${ }^{214}$ or acute psychological danger, ${ }^{215}$ or would impair his ability to tes-

1975), overruled, English v. McCrary, 348 So. 2d 293 (Fla. 1977); see also id. at 783 ("the personal preferences of litigants and a fair trial for litigants are two entirely different considerations"); Scott v. Scott, 1913 A.C. 417,438 ("[S]till less is it enough [to close a trial] that the parties agree in being reluctant to have their case tried with open doors.").

${ }^{208}$ In re Shortridge, 99 Cal. 526, 534, 34 P. 227, 230 (1893).

${ }^{209} \mathrm{Id}$.

210 See, e.g., Nixon v. Administrator of Gen. Serv., 433 U.S. 425, 457-460 (1977); Whalen v. Roe, 429 U.S. 589 (1977); Tavoulareas v. The Washington Post Co., 724 F.2d 1010, 1019-20 (D.C. Cir. 1984), reh'g granted en banc, No. 83-1688 (March 15, 1984).

${ }^{211}$ Indeed, Supreme Court cases indicate that first amendment interests of the press and public will often override an individual's right of privacy. See, e.g., Cox Broadcasting Corp. v. Cohn, 420 U.S. 469 (1975) (holding that accurate publication of the name of a rape victim obtained from judicial records cannot be punished as an invasion of privacy). In Press-Enterprise, Co. v. Superior Court, 104 S. Ct. 819 (1984), the Court acknowledged the possibility that a privacy concern might constitute a compelling interest sufficient to outweigh the public's right of access, but the Court did not indicate how the privacy concerns and the right of access should be balanced. On the facts before it in Press-Enterprise, the Court held that the privacy interest of jurors in avoiding public answers to embarrassing or traumatic questions during voir dire might be sufficiently protected by allowing jurors to answer particular questions in camera. Closing the entire proceeding was, therefore, unnecessary. Id. at 825 . Two Justices, however, wrote separately to emphasize that the majority opinion neither established a privacy right of prospective jurors, id. at 826 (Blackmum, J., concurring), nor diminished the public's constitutional right of access, id. at 829 (Marshall, J., concurring in the judgment). As a result, the extent of any right to privacy and its relation to the right of access to other judicial proceedings, such as civil trials, remains as much in flux after Press-Enterprise as before.

312 See supra notes 61-71 and accompanying text.

${ }^{213}$ See, e.g., In re Estate of Hearst, 67 Cal. App. 3d 777, 136 Cal. Rptr. 821 (1977) (probate court permitted to seal probate files of William Randolph Hearst if the family could substantiate their fears of physical attack by political groups).

${ }^{214}$ Id. at 784-85, 136 Cal. Rptr. at 825.

${ }^{218}$ In Globe, the Court recognized that preserving the psychological welfare of minor rape victims might necessitate closure under particular circumstances. 457 U.S. at 607-08. 
tify, ${ }^{216}$ the state's interest in protecting the privacy of that litigant would appear too attenuated and speculative to meet the "compelling interest" test.

This conclusion is buttressed by the fact that the public has a recognizable interest in the conduct of divorce litigation. The conduct of the judiciary is not of lesser public interest merely because divorce trials involve highly personal and particularized situations. To the contrary, divorce proceedings may call for heightened public scrutiny of the judicial process insofar as they make "extraordinary demands for compassion and sensitivity on the judge, the parties and the lawyers."217 Moreover, the commonness of divorce litigation creates a heightened public interest. ${ }^{218}$

Given the public interest in divorce litigation, trial closure should only be allowed where necessary to the administration of justice. ${ }^{210}$ The desire to be free from humiliation, insofar as it springs from the convenience and preferences of litigants and not from the need to ensure effective testimony, is not sufficiently compelling to justify even partial closure of divorce trials.

\section{ConcLusion}

The constitutional right of access to criminal trials should be extended to civil trials. Increased access to civil trials would bene-

Adults who must testify as to similarly humiliating experiences could conceivably suffer similar harm. The state's interest in protecting both litigants and the public from open testimony about sexual matters is reflected in the large number of state statutes allowing discretionary closure whenever a trial involves "vulgar or obscene" testimony. E.g., ArA. CODE § 12-21-9 (1975); see J. WIGMORE, supra note 90, § 1835(1) n.2.; see also Press-Enterprise, Co. v Superior Court, 104 S. Ct. 819 (1984) (discussing privacy interest of jurors subject to embarrassing questioning during voir dire), discussed supra note 211.

216 See Scott v. Scott, 1913 A.C. 417, 439 ("If the evidence to be given is of such a character that it would be impracticable to force an unwilling witness to give it in public" then closure may be necessary to ensure "the paramount object of securing that justice is done ... ."). Compare State v. Schmit, 273 Minn. 78, 85, 139 N.W.2d 800, 806 (1966) ("Mere embarrassment of adult witnesses with no showing of inability to testify" does not outweigh a criminal defendant's right to a public trial.), with Kirstowsky v. Superior Court, 143 Cal. App. 2d 745 (1956) (closure appropriate where witness's embarrassment made him unable to testify at all).

${ }_{217}$ State ex rel. English v. McCrary, 328 So. 2d 257, 260 (Fla. Dist. Ct. App. 1976)

(Smith, J., concurring in part), aff'd, 348 So. 2d 293 (Fla. 1977).

${ }_{218}$ State ex. rel. Gore Newspaper Co. v. Tyson, 313 So. 2d 777, 785 (Fla. Dist. Ct. App. 1975), overruled, English v. McCrary, 348 So. $2 d 293$ (Fla. 1977).

219 As the paramount object [of courts] must always be to do justice, the general rule as to publicity, after all only the means to an end, must accordingly yield. But the burden lies on those seeking to displace its application in the particular case to make out that the ordinary rule must as of necessity be superseded by this paramount consideration. Scott v. Scott, 1913 A.C. $416,437-38$. 
fit the public in several ways. First, public trust in the process of civil litigation would be strengthened. Second, the public interest in self-government would benefit from greater scrutiny of the judicial process. Third, the judicial process would itself be improved. A right of access to civil trials is therefore essential to furthering the first amendment's implicit protection of the public's right to be informed about the activities of government.

This comment has recognized that closure of civil trials must nonetheless be ordered when necessary to protect compelling state interests. Many traditional exceptions to open trials-such as the need to protect national security, trade secrets, or juveniles-meet this standard. The "compelling interest" exception is a narrow one, however, and only permits closure where an open trial would be incompatible with the process of justice or the state's obligation to protect its citizens from certain injury. Adopting these guidelines would ensure that the constitutional right of access to civil trials will be meaningfully exercised.

Jeanne L. Nowaczewski 